Ser, angústia e Poesia: uma leitura heidegGeriana

de Nauro Machado

Ricardo André Ferreira Martins*

RESUMO

O objetivo deste artigo é traçar um paralelo interpretativo entre a filosofia heideggeriana, sobretudo em seus conceitos mais conhecidos, e a poesia de Nauro Machado. Analisam-se, comparativamente, os principais conceitos, como estar-no-mundo (facticidade), ser-no-mundo (existencialidade) e vir-a-ser (angústia). Demonstra-se como cada um destes conceitos são extremamente elucidativos em uma abordagem existencialista da poesia de Nauro Machado, com ênfase, sobretudo, no conceito de angústia, tema central da lírica do poeta.

Palavras-chave: poesia, filosofia, facticidade, existencialidade, angústia.

INTRODUÇÃO

Dada a possibilidade de convergência, propomos, neste texto, uma intersecção entre o pensamento de Martin Heidegger e a poesia de Nauro Machado. Partimos da reflexão do filósofo alemão, para proceder a um transporte sistematicamente quase integral dos conceitos do primeiro, com o propósito de elucidar a perquirição poética do segundo. Com base nesse pressuposto, cabe observar que se trata de transporte que pode ser igualmente realizado no sentido de verificarmos a aplicação de uma reflexão fillosófica em outros campos da atividade humana. É óbvio, limita-se aí a aplicação ao universo de conceitos operacionais que, com efeito, permitem que tal procedimento não recaia em truísmos e falácias da ordem do senso comum.

O discurso filosófico e o texto poético evidentemente não se intercambiam e nem se excluem de forma necessária ou imperativa,

* Universidade Estadual do Centro-Oeste do Paraná, Irati, Paraná, Brasil.

E-mail: ricardoafmartins@gmail.com 
entretanto também não estão postos como símiles um do outro. O que desejamos - se é que é possível - é, ao realizarmos uma intersecção entre ambos, verificar como reflexão e linguagem são, conforme o próprio Heidegger, possibilidades de desvelamento do Ser através dos entes. Em certo ponto da reflexão heideggeriana, a filosofia e a problematização filosófica em torno da linguagem deixam de ser vistas, rompendo com a tradição platoniana, como possibilidade única ou superior a outras formas de desvelamento do Ser, de modo que a poesia, assim como a arte em geral, a mística, entre outros, passam a ser resgatadas como formas legítimas de tal desvelamento, retornando assim ao lugar de discurso de onde haviam sido expulsas pelo filósofo ateniense.

Além de Martin Heidegger, não há outro filósofo que tenha chegado ao grau de abstração que propicia a compreensão das distâncias e aproximações entre a poesia e a filosofia, pelo menos não com uma visão instrumental dos conceitos, mas a partir de uma cosmovisão que nasce justamente de uma problemática e, sobretudo, da vivência existencial.

Desse modo, o principal objetivo e objeto deste artigo é a proposta ou tentativa de demonstrar um vínculo ou relação de coerência entre a poética de Nauro Machado e a filosofia do Ser de Heidegger, demonstrando igualmente, além dos pontos de convergência, como o tema da angústia é candente em ambas as obras. Com isto, é nossa intenção fazer notar ao leitor como a conjuração de certos conceitos tornados caducos ou obsoletos pela historiografia e filosofia modernas como o Zeitgeist (Espírito do Tempo) - revela-se não apenas ineficaz e obtusa por vezes, mas, sobretudo, preconceituosa, ao repelir a possibilidade de uma consciência histórica coletiva que, mediante oposição ou confluência, realiza assim mais um desvelamento do Ser através dos entes históricos. Tomando isto como ponto de partida, comecemos antes por situar a reflexão heideggeriana na construção do texto.

Desde a antiguidade clássica, e mesmo antes desta, a filosofia ou mais propriamente o homem - questiona a razão de ser e de existir dos seres humanos, pondo em foco a nossa função e posição neste mundo e tendo diante de si um futuro desconhecido governado por forças ignoradas e escassamente manipuláveis, com uma única 
expectativa predeterminada e certa: a morte. Esse questionamento propiciou o florescimento das mais variadas respostas à perturbação intensa, chamada angústia - Angst (em alemão), ou La Nausée (a náusea, em francês) -, que se manifesta ao homem quando este, de forma deliberada ou provocada, sai de si mesmo e começa a assistir à vida e sua sucessão inexorável, na qual verifica assustado que está mergulhado e da qual os entes ao seu redor - seres humanos como ele muitas vezes ou não têm a mínima consciência ou procuram fugir para algum recanto do cotidiano para não ter de pensar em mais nada. Esta dúvida primária do ser humano possibilitou o surgimento de várias formas de religiosidade, pois um dos modos de silenciar ou apaziguar esta perturbação ou angústia - sobretudo para as grandes massas, que não estão isentas de grandes crises de angústia existencial - é transferir a dúvida para uma resposta além-vida ou além-morte, depositando todas as inquietudes nas mãos de entidades supra-humanas que contêm em si a chave de todo questionamento, na forma de uma promessa de felicidade eterna, que perdure além da existência humana.

Esta solução apareceria muitas vezes como um chamado ou uma voz interior - da qual nem mesmo a filosofia heideggeriana escapou -, pois as indagações humanas beiram muitas vezes o desespero devido à pura ausência de respostas e de lógica para todas as mazelas e misérias da humanidade. Todas as religiões, todas as formas de arte, todas as formas de mística ou de predestinação, toda a história da filosofia e mesmo da ciência, tudo isso tenta oferecer respostas para essa angústia (Angst, Nausée) que atordoa a existência humana, do mais simples e elementar ser humano até ao mais complexo e profundo.

No cruzamento de toda essa trajetória filosófica, surge o pensamento de Martin Heidegger. Como poucos de sua época, Heidegger soube perceber a miríade de feixes de angústia que povoam o nosso tempo, atravessado de cortes profundos como as grandes guerras, o holocausto - sem esquecer, é claro, a simpatia inicial do filósofo pelo nazismo - e o desenvolvimento estrondoso do capitalismo e de todas as suas perversões. A filosofia de Heidegger é essencialmente existencial, pois a existência é a essência do homem - o único ente que pensa e que sabe que carrega em si as forças que o conduzirão ao seu próprio fim -, e a missão que o filósofo deve tomar para si é desvelar a existência e determinar, através da reflexão ativa, o ser da existência. Negando 
a filosofia kantiana, Heidegger desconsidera a existência de conceitos a priori, uma vez que todos os conceitos estão postos e se resolvem na existência, ao longo do existir, no acontecer histórico. Heidegger observa igualmente que, ao longo do desenvolvimento da história da ciência, é possível detectar o movimento que nos revela a possibilidade da existência sem a necessidade da ciência. Porém, a sociedade de consumo, instituída pelo capitalismo, impõe-nos uma forma existencial na qual esta possibilidade não está mais colocada ao nosso alcance; ou seja, de tal modo estamos incrustados na rede de significações do mundo tal como o conhecemos hoje que a própria sociedade de consumo prevê que não teremos como escapar, por nossa própria vontade, de sua malha de representação do real, uma vez que sem a ciência e a tecnologia não conseguimos imaginar outro mundo.

A ciência e a tecnologia formam e informam, quando não deformam, a compreensão que temos da existência e da realidade, impossibilitando ao homem comum sair de si ao encontro do ser, que o permitiria, talvez, vislumbrar o Ser. Portanto, o ser humano ou o ser homem, denominado por Heidegger Dasein - estar em, ser aí, ser aqui -, ou seja, o homem como um ser-no-mundo, é o objeto a partir do qual o filósofo alemão realizará a sua reflexão sobre os modos de desvelamento do ser no mundo, ou melhor, na existência. É necessário que o homem, lançado ao mundo de forma passiva, possa descobrir por livre e própria iniciativa o sentido da existência, superando a facticidade do estar-no-mundo para que possa atingir o estágio de Existenz, ou seja, a pura existência do Dasein. ${ }^{1}$ Com esta proposta, Heidegger deseja rever o projeto da metafísica em novas bases, partindo do método fenomenológico de Husserl, seu mestre. A principal crítica de Heidegger se dirige, portanto, à filosofia moderna, por ter esquecido o Ser e ter se voltado exclusivamente para o conhecimento.

Para Heidegger, em um sintoma típico da reflexão fenomenológica, a problemática Sujeito versus Objeto não existe, pois o homem não está separado do mundo, da existência, da história e do tempo, em uma atitude de contemplação. O homem é parte integrante do mundo, um ente entre os entes do mundo, tendo consciência de sua finitude e de sua existência como ser para a morte, diferencial máximo, segundo Heidegger, dos outros entes. 
Desse modo, para o filósofo alemão, a história do homem, através da ciência, é "a história do esquecimento do ser", da motivação que conduziria o homem a procurar um sentido para a sua existência, única condição através da qual o ser humano poderia afinal abrir uma senda para o desvelamento do Ser. Com isto, retomando a herança deixada por Rousseau e suas críticas ao Iluminismo, desembocadas no oitocentos sob a forma do movimento romântico, a única realidade que importa ao homem, segundo Heidegger, é aquela cuja apreensão se dá de forma concreta, porém singular, insólita, que o homem pode tomar para si subjetivamente. O que interessa, pois, é a subjetividade, pois "a subjetividade é a verdade, a subjetividade é a realidade e o universal não passa de mera abstração do singular" (apud PENHA, 2001, p. 16).

Existir é, pois, ser no mundo engajado, realizar a possibilidade de sua existência, o que será tomado pelos existencialistas, a exemplo de Sarte e Camus, como um ato definidor da essência. Para existir, ser no mundo, conferir essência à existência, há a necessidade de um ato que defina esta última. Somente este ato pode, com efeito, atribuir essência - sentido - à existencialidade humana. O ser humano seria, portanto, apenas uma possibilidade do Ser que se determina ao longo do decurso do tempo, porém o ser do ser humano se define no curso da existência, que é o tempo que lhe cabe em busca do sentido e da essência desta última.

Heidegger apregoa este retorno às origens da filosofia, propalando a necessidade de uma busca da essência do ser. Nauro Machado também o faz em sua poética, na medida em que propõe que o homem se volte às forças primordiais e primitivas da existência, sobretudo as sexuais, de sua condição existencial, a fim de viver uma sexualidade ontológica que o faça perceber como um ser de carne, ossos, sexo e genitália, para que assim tanto a miséria quanto a singularidade da existência possam despontar acima da banalidade diária.

Assim como em Heidegger, também em Nauro Machado há a luta por retirar o ser humano de seu estado de reificação, diante das coisas e entes úteis que o desviam de um olhar atento para si mesmo. A poesia pode sacudi-lo nesta direção, ao passo que a filosofia o captura definitivamente. Para tanto, é necessário observar que em Heidegger, assim como em Nauro a angústia revela-se como um ponto nodal das preocupações de ambos, posto que a angústia não é simplesmente um 
estado psíquico ou uma emoção ordinária, mas algo que permite a percepção do ser-aí, que põe o ser humano em condição de Dasein, diante de si mesmo e do estar-no-mundo, para talvez perceber o ser-nomundo e do ser com o nada.

A angústia é, assim, o momento privilegiado que permite ao ser humano se dar conta de sua existência, pois é justamente o momento em que o ser se dá e se revela; ainda não é o Ser, mas uma das formas (a primeira) de o Ser se mostrar, se desvelar ante os olhos e para a subjetividade. A realidade concreta então surge como algo singular e insólito, e o homem se dá conta de sua singularidade como Dasein, como ser aí, ser aqui, ser no mundo, mudo e atônito. Neste momento, surge a necessidade da Linguagem, pois é na palavra, na Linguagem, que as coisas, os entes, para Heidegger, chegam a ser; o homem, fazendo-se linguagem do ser, vem ao encontro de si mesmo, vem a si mesmo e, desse modo, o mundo vem ao homem, em toda a sua plenitude sensorial e existencial.

A Linguagem, ${ }^{2}$ para Heidegger, é a "Casa do ser", pois é na Linguagem que habita homem como fundamento, é por meio da Linguagem que o homem apreende a realidade e vela e desvela a si mesmo. Dessa forma, a linguagem constitui o fenômeno mais característico do ser e da essência humanos, uma vez que é somente através de uma linguagem conveniente que se torna possível o afloramento da verdade de todas as coisas, na qual se revela o fundamento de todo o existente, de todos os entes que existem. Para Heidegger e o seu projeto metafísico, a filosofia necessita retornar ao questionamento do ser e à busca do fundamento que o constitui, utilizando a linguagem como instrumento para desvelar, uma linguagem em que as relações entre sujeito e objeto não estivessem mais postas, em que o Ser pudesse dar a se conhecer plenamente. Para tanto, a linguagem deve retornar ao logos grego, para que ela, como base e fundamento do real, propicie a revelação e a exposição dos fenômenos de maneira clara, pois o homem, único entre os entes da natureza a possuir uma língua capaz de nomear o Ser, é aquele ser que detém o privilégio de resposta de como o "ser-aí" (Dasein) deve ser apreendido em sua manifestação temporal.

Heidegger se põe contra a interpretação aristotélica de metafísica, na qual o homem perde a sua humanidade intrínseca ao ser posto apenas como um ente entre os demais. Com isto, o filósofo alemão pretende 
demonstrar como as relações entre as coisas existentes são efêmeras e vinculadas ao modo e ao tempo em que elas surgem. Como decorrência de sua manifestação temporal, o fenômeno, no tempo, traria consigo o próprio sentido do ser, enquanto o homem, portador de linguagem e contemporâneo do ser, devido a sua existência ser contígua ao ser, teria a chance de compreensão do "ser-aí" manifesto no tempo.

Para atingir esta compreensão - este entendimento do Dasein -, torna-se necessário abandonar a perspectiva do "ser-aí" como um objeto fixo de estudo, através do qual criamos e aplicamos categorias e imperativos reificadores, os quais transformam o ser em uma mera coisa, sujeita à experiência puramente concreta. Ao contrário, são vários os modos de manifestação do ser e de como este desvelaria a sua essência no tempo, impossibilitando, assim, o projeto aristotélico de classificação em categorias atemporais. Isso se deve ao fato de Heidegger acreditar que o homem é o portador da verdade e que esta se encontraria preservado no interior de sua essência, sendo revelado por meio de uma reflexão radical cujas origens estariam no pensamento présocrático. Quando Sócrates põe em suspensão a validade do mito como modelo interpretativo para o desvelamento do ser e Platão estabelece a diferença entre uma linguagem verdadeira e uma falsa, expulsando os artistas e os poetas da república ideal e instituindo noções mais legítimas de investigação e pesquisa científica, a filosofia ocidental impede a manifestação de formas válidas de reconhecimento do ser, provocando, desse modo, o seu progressivo esquecimento e tornando a sua verdade imanifesta.

Antes de partirmos para a análise do tema em si, convém traçarmos um caminho. Para tanto, tomemos a concepção heideggeriana de existência humana, constituída, conforme o filósofo, por algumas características fundamentais: a) facticidade; b) existencialidade (ou transcendência); c) a angústia. Estes tópicos serão explicitados para passarmos ao ponto nodal deste artigo, que é o confrontamento da filosofia do ser de Heidegger e a poesia existencial de Nauro.

\section{ESTAR-NO-MUNDO: FACTICIDADE}

A facticidade diz respeito ao fato de o homem, ser para a morte, estar jogado, atirado no mundo à revelia de sua vontade, sem qualquer 
participação sua no tocante a escolhas ou decisões. Neste sentido, a facticidade do homem é a sua presença (pré/ente), um ente que se encontra em um estar-lançado no mundo, carregando em seu ser as condições de possibilidade de sua presença. $\mathrm{O}$ mundo, no entanto, no qual o homem está lançado, é constituído não apenas pela phisys ${ }^{3} \mathrm{e}$ tampouco está reduzido a uma interpretação física. Ele representa a totalidade ou o conjunto de condições sócio-históricas, socioeconômicas e mesmo geográficas nas quais o indivíduo se encontra, como ser-nomundo, totalmente imerso. Esta facticidade não diz respeito a um acaso, um acidente, uma vez que o estar-lançado no mundo também traz como consequência o fato de ser, tendo de ser-no-mundo, negando a reificação absoluta e postulando a sua presença como existente, afirmando a sua existência diante da totalidade de entes do universo.

A partir de uma interpretação existencialista, esta negação da facticidade surge como condição de possibilidade para uma busca de transcendência. Para a poesia de Nauro, a existência do homem como ser lançado no mundo, vivendo este estar-lançado em sua materialidade física, traz consigo a possibilidade do homem, cindido em sua individualidade pela reificação reinante, de estilhaçar as forças que comprimem o Dasein, impulsionando o ser para a sua plenitude. Isto se dá, entretanto, por uma operação, uma outra espécie de cirurgia ou constatação ontológica que, em Nauro, conforme já referido em situações anteriores, parte de esquema de gineceu. Nesse esquema, a sexualidade apresenta as condições para que o ser aí perceba a sua presença, o seu estar-no-mundo, de uma maneira em que a facticidade dos entes circundantes seja negada pela condição extrema de ser-em-si, sem mais nada além de sua ostentação:

Quando, num livro de obstetra, - tinha eu talvez tão só dez anos -,

vi a genitália aberta, abjeta, e vi a imensa sujeição do ânus, senti-me ter a alma de poeta: um mar entre dois oceanos.

Nasceu dali este meu destino, como se daquela cabeça, daquele feto de menino, 
daquela flor tão-só crueza, pudesse a dor também ser sino e a miséria também grandeza!

(MACHADO, 1987, p. 23)

Tal como Heidegger, Nauro Machado também expõe a diferença radical entre o ser o e o ente. $\mathrm{O}$ "ser-aî" é aquilo que é característico do homem, mas apenas o homem existe como um "ser-aí" capaz de revelar-se, em uma tomada de consciência como a oferecida por meio da linguagem. O homem tem, portanto, a possibilidade de vir à tona de si mesmo e apresentar-se enquanto tal, ou seja, como um ser que se manifesta no tempo, dotado de temporalidade e existência. Como é um "ser-aí" dotado de linguagem, o homem reúne as condições necessárias para uma ocorrência singular: a manifestação do próprio ser no tempo, não mais como um simples objeto de especulação científica ou filosófica, mas por intermédio de uma subjetividade devastadora e angustiante, na qual sujeito e objeto estão unidos indissoluvelmente em um pensamento original e originário. A poesia, portanto, é uma das formas mais legítimas de superação da relação sujeito-objeto imposta pela teoria do conhecimento desde quando Platão fez a célebre separação entre uma linguagem verdadeira e uma linguagem falsa, promovendo assim a expulsão dos poetas da pólis grega. Ora, a concepção heideggeriana de linguagem permite o retorno dos poetas para o centro da pólis - a ágora -, pois a linguagem poética possibilita uma das formas de desvelamento do ser. A facticidade, por outro lado, que é o estar-lançado no mundo, é anulada no momento em que o homem, ao se questionar sobre a materialidade de sua existência e de sua presença física, percebe que não foi consultado. A factualidade da existência, segundo Heidegger, nos obrigaria a uma condição de "ser e ter de ser", absolutamente impositiva e castradora da condição humana essencial:

Esse "fato de ser e ter de ser", aberto na disposição da pre-sença, não é aquele "fato" que, do ponto de vista ontológico-categorial, exprime a factualidade pertencente ao ser simplesmente dado. Esse só se faz acessível numa constatação observadora. Em contrapartida, deve-se conceber o fato aberto na disposição como determinação existencial deste ente que é, no modo de ser-no-mundo. Facticidade 
não é a fatualidade do factum brutum de um ser simplesmente dado, mas um caráter ontológico da pre-sença assumido na existência, embora desde o início, reprimido. $\mathrm{O}$ fato da facticidade jamais pode ser encontrado numa intuição. (HeIDEGGER, 1997, p. 189)

O lirismo de Nauro é, com efeito, uma negação da facticidade do mundo, mas também uma procura de sua transcendência por meio da existência, conforme Hildeberto Barbosa Filho (2005) o menciona. Somente por meio da existencialidade, portanto, é que o ser humano poderia atingir uma transcendência da condição de facticidade, de estarlançado-no-mundo. A obra lírica de Nauro, amplamente consciente deste compromisso ontológico, desde o início lançou os fundamentos desta investigação:

Meu corpo está completo, o homem - não o poeta.

Mas eu quero e é necessário

que me sofra e me solidifique em poeta,

que destrua desde já o supérfluo e o ilusório

e me alucine na essência de mim e das coisas,

para depois, feliz ou sofrido, mas verdadeiro,

trazer-me à tona do poema

com um grito de alarma e de alarde:

ser poeta é duro e dura

e consome toda

uma existência.

(MACHADO, 1980, p. 5)

O homem, saído de sua condição de facticidade - como este belo poema o atesta -, toma consciência de sua condição de estarno-mundo, assume a percepção de seu corpo - prova incontestável de sua individualidade objetiva e também subjetiva - e parte para a procura de uma outra condição de ser: a do poeta. O poeta, como ente liberto das coerções da linguagem ordinária, permite ao homem aceder às camadas mais profundas do ser e da essência humana; para isso, entretanto, faz-se necessário que o supérfluo e o ilusório da facticidade sejam literalmente destruídos, a fim de que o poeta possa encontrar a essência do ser na percepção de si próprio e das coisas - ou seja, todos os entes -, a verdade e o fundamento do ser, independentemente se feliz 
ou sofrido. O projeto desta procura ontológica tem de consumir toda uma existência, pois não se encerraria nesta tomada de consciência que, segundo Heidegger, ainda não é a percepção do ser, mas dos entes, pois o ente é o particular, o ôntico, ${ }^{4}$ enquanto o ser está além da finitude do homem, sendo que esse "além" não é metafísico ou religioso, mas no presente, no aqui e agora. Esta tomada de consciência - grito de alarma ou alarde - é uma transcendência no sentido da superação da facticidade na existência e, portanto, existencialidade.

\section{SER-NO-MUNDO: EXISTENCIALIDADE}

A existencialidade ou transcendência é na verdade o que Heidegger define por ser cotidiano, o qual se manifesta por intermédio dos atos das coisas do mundo, a partir de cada indivíduo, como o modo particular de ser do ente que é o homem. A existência é uma abertura permanente do ser-no-mundo e, paralelamente, a expressão da cotidianidade de sua presença, tanto em sentido pessoal como em sentido ordinário: o da repetição de uma rotina. Ora, a existência como tal já carrega consigo a condição necessária para a sua transcendência - a superação da facticidade-, pois o ser humano, ao tomar a percepção do ser-no-mundo, já era existente e, portanto, um ente que era um pré de si mesmo. No ser humano, por conseguinte, encontra-se a antecipação de sua própria existencialidade, de sua transcendência, como possibilidade. Essa possibilidade se manifesta, logo, no cotidiano, pois enquanto estivermos acostumados à vida diária e às suas limitações não perceberemos o que dá fundamento às nossas relações conosco mesmos, com o nosso ser. O nosso ser está oculto, portanto, na entificação e reificação do cotidiano. O ser humano é, consequentemente, um ente cujo ser está sempre em jogo, em possibilidade e em abertura, ao mesmo tempo em que tem a percepção de sua diferença em relação aos outros entes. $\mathrm{O}$ homem, logo, não é algo completo, conforme nos adverte Nauro em seu poema "Parto" (1958), mas um ser que se define ou é gerado - parido, se seguirmos a metáfora naurina - em um projeto - no caso, um poeta. O homem é, assim, um ente inacabado, cuja essência confudimos com a sua existência, ${ }^{5}$ somente concebido como um mero estar no mundo, sendo o que Heidegger define como Dasein. 
Desse modo, a consciência de ser-no-mundo, conforme a concepção heideggeriana, pressupõe uma responsabilidade, um verdadeiro desafio à capacidade de transformação do ser humano, que necessita encontrar um projeto de existência, a fim de se tornar aquilo que planejou e que deseja, pois a verdadeira consciência de ser e estarno-mundo provém de uma negação da impessoalidade - uma vez que esta nos é imposta pelo cotidiano em que todas as coisas têm de inserir-se como úteis - e a afirmação da pessoalidade. Entendamos pessoalidade como a manifestação objetiva da subjetividade, no sentido de que as possibilidades de ser devem surgir de uma compreensão ou interpretação do ser-no-mundo cotidiano, de modo a expulsar os modos de ser completamente impessoais, que anulam a subjetividade.

Ora, apesar de em muitos momentos a literatura e especialmente a poesia afirmarem justamente o contrário - negação da subjetividade em prol da objetividade -, não resta a menor dúvida de que a linguagem poética é uma das manifestações humanas que mais têm resistido à impessoalidade da linguagem, um projeto essencialmente racionalista que, ao longo do desenvolvimento da modernidade, vem sendo implementado por todos - a exemplo dos iluministas e dos positivistas que desejam, como Platão, separar uma linguagem verdadeira de uma falsa, incluindo aí todas as formas em que o desvelamento do ser ocorreria: narrativa, literatura, poesia, música. A consciência do projeto lírico de Nauro, entretanto, é um explícito compromisso - no sentido da responsabilidade ontológica com a existencialidade - com o combate a esta redução do ser-no-mundo à impessoalidade, em que não se manifestaria uma subjetividade pronta a implodir todo o edifício que anula a particularidade do ser em cada um de nós. Ao contrário, em todos os momentos de sua poética, Nauro procura sondar a presença e manifestação do ser em tua totalidade: é no próprio movimento da linguagem que o ser se desdobra, se revela e se desvela, ao renunciar solenemente a palavra reificante do ente, que se anula ao renegar o diálogo com o que de mais íntimo possuímos - a voz interior da subjetividade - para assumir um papel redutor de mecanismo acessório da linguagem técnica. A existencialidade, em sua tomada de consciência, faz com que o poeta busque a palavra do Ser, oculta entre as dobras da linguagem, de modo a que ela se revele como presença, como palavra em que o ser é puramente palavra, palavra-ser: 


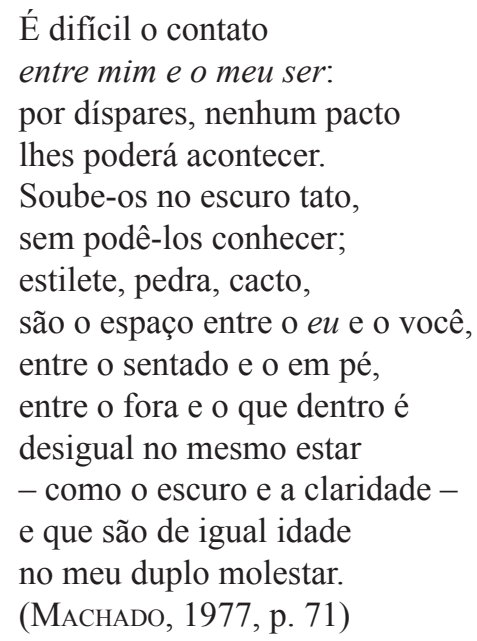

Portanto, quando Heidegger afirma que a existência humana é uma possibilidade de ser-no-mundo, significa dizer que nossa obrigação é superar a facticidade do estar-lançado por intermédio da existencialidade do ser-no-mundo. É quando o ser humano adquire a responsabilidade de se projetar, a fim de poder ser e, para tanto, precisa fazer da vida um projeto de ser, de um vir-a-ser que permita completude e integração com outros modos de ser existentes. Isto, em suma, é uma filosofia da ação: somente por meio de um projeto posto em prática é que podemos definir de maneira eficaz a totalidade do ser que nos compete. O projeto lírico de Nauro é, antes de mais nada, a consciência inescapável desta fuga ontológica no plano existencial, onde o ser se dá a conhecer:

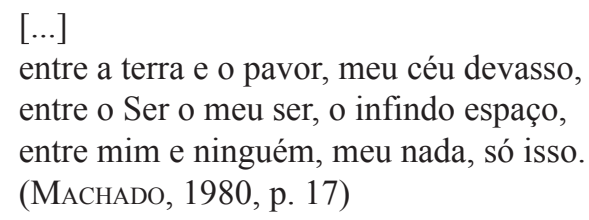

Todavia, vivemos cercados de objetos em pleno cotidiano, objetos que são usados sem pensar, sem qualquer reflexão. A partir dessa situação corrente, o Dasein percebe que está enredado em um mundo cheio de objetos úteis, de utensílios, de instrumentos (Zeug). Dessa situação imediata, há duas perturbações que saltam à vista: a) quando 
um objeto se apresenta sem utilidade, ele se encontra na situação de um ente não existente no sentido concreto - sem utilidade para a rede instrumental que o significa. O instrumento deslocado, portanto, da rede instrumental que o significa permite a teoria (theorein) no sentido grego: observar sem interferência, resultando assim uma situação de pura contemplação do objeto em sua condição original de ser-em-si. É, pois, naquele preciso momento em que o objeto é destacado da rede instrumental que o Dasein observa aquele ente no seu ser em si, desprovido de utilidade. Dessa situação de confronto com os objetos e conosco mesmos -, destacados de nossa relação de utilidade do cotidiano, é que provém o espanto, a constatação de ser-no-mundo que permite a tomada de consciência e posteriormente a tomada de uma ação por meio de um projeto que definirá o nosso ser. A poesia, em sua condição de não utilidade da linguagem, nos devolve à condição de serem-si, na medida em que nos põe em contato com a nossa não utilidade, de modo a perceber que o ser se manifesta fora da rede intrumental de objetos cotidianos, de relações quotidianas desprovidas de uma relação mais profunda com o ser. Com este espanto, vem a percepção do singular, do ímpar, o choque com o mundo extraído de sua utilidade cotidiana, posto em si somente, com o seu ser:

Se escrevo, ou se não escrevo, é a mesma trampa.

Que eu diga, ou não me diga, é tudo igual.

O singular nos soca, tapa e tampa.

A diferença é sempre o desigual.

Escreves de água tua funérea campa.

Com água escrevo: sou pobre animal.

Ó desespero: minha última rampa

para querer-me múltiplo, plural!

Ver-se criança à túrgida sacola

no ímpar segredo dado àquela bola

feita incomensurável noutros pés.

Jamais voltar não podes para a frente.

O singular é todo teu, é o teu rente.

O singular são os meus dedos. Os dez.

(MACHADO, 2002, p. 291)

Outra questão importante a considerar é que, qualquer que seja o projeto escolhido por um homem entre as muitas possibilidades que lhes 
são apresentadas, uma certeza paira acima de tudo: a morte. Assim como para Heidegger, também para Nauro a morte é uma experiência-limite, a única que se apresenta como pessoal, incomunicável e instransferível, pois somente podemos conhecer a morte dos outros, pois para nós a própria experiência da morte é vedada. A morte pode ser vivida não como experiência, mas como possibilidade existencial; somente esta possibilidade - uma vez que está dada desde o princípio da existência pode, com efeito, conduzir o homem a um amadurecimento diante do cotidiano, ultrapassando o limite do estar-lançado no mundo. É mais que uma experiência ordinária, como a de um ente que simplesmente está-aí, lançado no mundo, de forma impessoal e sem subjetividade. O homem é um ser que está lançado para a morte; é um ser para a morte, que é o nada, a possibilidade última que define, por si só, a condição humana e a existência.

Uma existência somente pode ser considerada autêntica, segundo a visão heideggeriana, com uma consciência desperta para a morte, pois é este momento indevassável que define o que é a existência, acima de qualquer outra eventualidade ou situação empírica, na qual o ser tem meios para intervir diretamente. É essa consciência plena que define o homem:

Todas as cifras não somam uma só vida.

Todas as moedas não impedirão que o homem caminhe resoluto para o ventre da alma.

(Machado, 1975, p. 81)

\section{VIR-A-SER: ANGÚSTIA}

Segundo Martin Heidegger, a angústia só se dá a partir de um entendimento do tempo, pois é uma experiência radical do futuro, essencialmente radical, que consiste em antecipar a morte, ter consciência de um ser para a morte. No cotidiano ordinário, somos levados a não pensar na morte, mas apenas na rede instrumental de objetos úteis, que são impostos ao nosso desejo e às nossas existências, as quais, mergulhadas na reificação, esquecem-se do ser, do fundamento de nosso verdadeiro si-mesmo. Portanto, a angústia não é um mero sentimento, tampouco uma patologia a ser combatida como sintoma 
de um estado depressivo, pois a rede instrumental nos obriga a sufocar nossas sensações e percepções mais verdadeiras para nos inserirmos entre os acessórios utilitários e sermos, nós mesmos, úteis aos outros.

O ser humano, a partir de sua individualidade, desde o princípio, é posto em uma situação de sacrifício e anulamento da subjetividade, sendo a todo o momento acossado pelas coerções da sociedade - dos outros, dos "eles" -, que tenta patologizar os sentimentos não úteis: angústia, espanto, aflição, medo da morte. Devido esta violência contra a subjetividade, em nosso cotidiano ordinário somos obrigados a conduzir uma vida promiscuamente pública, uma vida igual e limitada à vida "com" os outros. Refere-se a um tipo de coerção somente conduzido no sentido de transformar o indivíduo em um ser impessoal totalmente alienado e afastado de sua primordial tarefa no mundo: alcançar o desvelamento do ser; enfim, tornar-se si mesmo. O futuro, que é a morte, está oculto pela rede instrumental que nos oprime em nossa trama de relações impessoais com os outros; a morte, portanto, só se revela em uma situação de angústia, como antecipação ou premeditação de uma experiência radical, pela qual, inevitavelmente, todos passarão.

A angústia deixa-nos perplexos diante da existência, pois, ao contrário do que insistentemente a rede instrumental nos mostra, há na verdade uma espécie de ilusão de estar no mundo que nos impede de ver a realidade. No cotidiano ordinário, o tempo é uma percepção apenas, uma noção de tempo tradicional que, portanto, não serve para pensar o homem, já que este é uma possibilidade, um ser para o futuro. Qualquer antecipação do futuro, o fazemos a partir do presente, sendo o presente o ponto a partir do qual definimos a nossa ação, o projeto que nos permitirá ir ao encontro do nosso ser. Em suma, a angústia é o único sentimento que pode devolver o homem à totalidade do ser, por intermédio do autoconhecimento e da autorreflexão, formas de desvelamento impedidas de se manifestar em nós em função das coerções impostas pelo cotidiano ordinário, que nos anula e nos obriga a sermos impessoais:

Ocupo o espaço que não é meu, mas do universo.

Espaço do tamanho de meu corpo aqui, enchendo inúteis quilos de um metro e setenta e dois centímetros, o humano de quebra. 
Vozes me dizem: eh, tu aí! E me mandam bater serviços de excrementos em papéis caídos numa máquina Remington, ou outra qualquer. E me mandam pro inferno, se inferno houvesse pior que este inumano existir burocrático. E depois há o escárnio de minha província. E a minha vida para cima e para baixo, para baixo sem cima, ponte umbilical partida, raiz viva de morta inocência. Estranhos uns aos outros, que faço eu aqui? E depois ninguém sabe mesmo do espaço que ocupo, desnecessário espaço de pernas e de braços preenchendo o vazio que eu sou. E o mundo, triste bronze de um sino rachado, o mundo restará o mesmo sem minha quota de angústia e sem minha parcela de nada.

(MACHADO, 1971, p. 48)

Ora, a angústia em Nauro, mais talvez que qualquer outro tema perceptível, sempre foi tematizada, além de comentada por todos seus grandes críticos. A angústia desta lírica é aquela que justamente, tal como em Heidegger, conduz o homem à percepção do si-mesmo, de sua alienação face às opressões do cotidiano ordinário. É esta angústia que salta aos olhos, como procura inquietante da essencialidade do ser, ainda que haja a possibilidade, todo o momento posta diante de nós, de nos recolhermos novamente ao esquecimento do mesmo ser. A todo o momento, o cotidiano ordinário e habitual nos impõe retornar a ele, superar a angústia e seu poder de transcendência em relação ao mundo, abandonarmos o projeto essencial que nos conduz à descoberta do simesmo e da autenticidade existencial. Estamos sempre cercados pela impessoalidade, sobretudo quando somos nivelados pela mediocridade e ficamos mergulhados no cotidiano mecânico e repetitivo. Porém, é justamente isto que gera no ser humano o sentimento de angústia, uma vez que a precariedade da condição humana é patente e visível, de tal modo que não suportamos a neutralidade e o anulamento da subjetividade.

Somente a violência da angústia cria, portanto, este "piscar de olhos", este clarão dentro da existência que ilumina a procura do ser. 
Lançado pela angústia no universo da impessoalidade, o mundo se apresentará como a realidade do ser-aí-com - ao mesmo tempo, ao lado, de forma contígua, exatamente como estamos dados no mundo. O serno-mundo, a partir de uma antecipação de si mesmo, uma preocupação consigo próprio, escapa do cotidiano para outra situação, na qual procura entender a si e realizar o projeto de uma experiência singular, pois o Dasein é uma possibilidade, algo em abertura para o ser:
A dor de ser, do ser fatal senhora, a dor de ser, do ser feroz patroa, é instante só, mas que no ser demora, e dura, e fere, para que mais doa. É dor da eternidade morta em hora, é dor de estar no ser, a coisa à toa, a coisa passageira, qual vã aurora tornada em noite, a que ninguém povoa. Somente o verde oculta o verde à flor. Não posso eu ocultar-me noutro ser nem pode outro dizer-me em mim: eu sou. Ó ser do ser mortal, ó ringue, ó lona: se o início e o fim são só meus, podeis crer que a dor é a ladra da minha alma. A dona. (MACHADO, 1975, p. 90)

\section{CONCLUSÃo}

Ao longo da obra de Nauro, considerando o tópico da angústia, percebe-se que esta se manifesta por uma necessidade premente de investigação do eu, que questiona o universo de aparência e tensão ao seu redor. No que diz respeito à questão de uma experiência singular, de um projeto que reconduza o homem ao encontro de si mesmo, ressaltese que esta projeção sobre o mundo e a existência não é solitária, pois o homem é um ser-com, em relação com outros homens, conforme se percebe no poema anterior. Somente em relação a si mesmo e à premeditação do seu futuro, em uma constante preocupação e cuidado (Sorge) consigo próprio é que o homem pode alcançar a transcendência do cotidiano habitual, uma vez que é um ser incompleto. Além disso, o homem tem diante de si inúmeras possibilidades de ser a cada momento, 
para as quais uma infinidade de alternativas está aberta, o que ocasiona um estado tensional entre o que ele é o que pode vir a ser.

Por esta razão, a angústia tanto em Heidegger como em Nauro é fundamentalmente diversa do temor de um ser para a morte; a angústia não se dá através de um desespero, ao modo de Kierkegaard, mas por meio de uma paradoxal serenidade, pois ela não pode impedir o homem de autoconhecimento e de ação. A angústia, aqui, não se confunde com o nada, pois é o nada que se manifesta através dela, ao mesmo tempo em que o ente em sua totalidade ontológica. Somente ao adquirir consciência da determinação do estar-no-mundo por meio da angústia é que o homem passa de uma existência banal e ordinária para uma existência autêntica, e faz uma escolha: a vida banal e a vida autêntica. A linguagem poética que procura o desvelamento do ser nos coloca sempre diante desta escolha, na medida em que ficamos frente a frente com a angústia originária, a qual não é desperta em função de uma eventualidade insólita e tampouco é um estado em oposição à alegria, no sentido da perspicácia e da atenção, mas é um sentimento que pode surgir a qualquer momento em meio ao ser-no-mundo, pois é constitutivo de nossa natureza sempre em inquietação.

Não é possível que um homem, em algum momento de sua vida, não deixe abandonar-se ao sentimento de desajuste, de náusea ante uma existência que impõe uma forma de ser impessoal, nestes momentos em que nos sentimos simplesmente abandonados e suspensos no nada. Esta angústia está sempre lá, oculta pela rede instrumental das relações sociais, de modo que a qualquer instante pode nos assaltar, uma vez que o homem nunca se coloca diante do nada por livre e espontânea vontade, por decisão própria; ela sempre se coloca diante de nós quando transcendemos a condição de ente em puro estar-aí, quando a morte, súbito, está diante de nossos olhos atônitos, sinalizando o nada à nossa frente. Como Nauro deixou sugerido em seu livro intitulado Funil do Ser, a poesia é uma busca, mais que uma inquirição, do que é o ser existencial: "Este volume de poemas curtos reflete uma tentativa existencial, através do que ousei chamar de funil, em busca de meu hipotético ser. Sua forma acompanha assim o ritmo próprio das canções mínimas, no encolhimento cada vez mais estreito da minha finitude temporal". ${ }^{6}$ A angústia, pois, como forma de desvelamento do ser, empurra-nos ao horizonte da finitude existencial, cuja temporalidade 
intrínseca é inescapável, ao modo de um relógio, uma ampulheta cujo funil esgota o tempo de nosso ser a cada segundo. Não resta, portanto, nenhuma outra forma de contemplação do si-mesmo que não através da solidão final, que aguarda a todos nós:

\author{
Não Contigo: \\ só comigo, \\ só meu ser, \\ e no Todo \\ - que é o do lodo - \\ ainda ter \\ tudo em mim: \\ sexo e rim \\ e razão, \\ mas eterno \\ como o inverno \\ e o verão. \\ (MACHADO, 1981, p. 87)
}

BEING, ANGUISH AND POETRY: A HEIDEGGERIAN LECTURE OF NAURO
MACHADO's WORKS

\title{
AbSTRACT
}

The objective of this article is to draw an interpretative parallel between the heideggerian philosophy, primarily to its most well-known concepts, and Nauro Machado's poetry. We comparatively analyze the essential concepts, such as stay-in-world (facticity), be-in-world (existenciality) and come-tobeing (anguish). We demonstrate how each one of these concepts is extremely elucidating in an existentialist approach to the poetry of Nauro Machado, with emphasis above all on the concept anguish, the central theme of the lyrical of the poet.

KEY wORDS: poetry, philosophy, facticity, existenciality, anguish. 


\section{Notas}

1 De acordo com o "glossário alemão", em A morada do ser, de Conceição Neves Gmeiner, Dasein "significa existência, vida. Como verbo: estar presente, ter vindo, existir e, Da-sein, ser-aí, formado de Da, aí e sein, ser. Separados os dois termos, tornam-se independentes e ganham um novo sentido para o termo final Da-sein". Conforme as "notas explicativas" de Ser e tempo, Márcia de Sá Cavalcante - apesar de o termo Dasein ser traduzido como existência ou "ser-aî" - opta pelo termo "pre-sença". Citando uma entrevista conferida por Heidegger ao Der Spiegel (Revista Tempo Brasileiro, n. 50, jul.-set. 1977), afirma que é "na presença que o homem constrói o seu modo de ser, a sua existência, a sua história etc.".

2 A Linguagem (com "l" maiúsculo) é a "Casa do ser", segundo Heidegger, pois nela habita o homem, ao passo que a linguagem (com "l" minúsculo) é apenas a concepção lógica, gramatical, filosófica e científica através da história ocidental. A primeira é o fundamento; a segunda, o fundado.

3 Termos como physis (em grego, "natureza"), dasein (em alemão, "ser-aí"), ousia ("substância" ou "essência" grega) e Zeit ("tempo", alemão), não são apenas um vocabulário empregado pelos helenos e alemães em filosofia, mas apropriado pelo pensamento heideggeriano. A linguagem, para Heidegger, é o elemento mais peculiar da essência humana, pois somente por meio de uma linguagem adequada é possível o afloramento da verdade de todas as coisas, o fundamento de tudo. A metafísica heideggeriana é, portanto, um profundo questionamento do ser e uma procura de seu fundamento, utilizando a linguagem originária como um instrumento de acesso ao níveis mais plenos da essência humana.

4 No nível ôntico, o "ser-aî" é uma determinação da presença do ser, entre os entes. No estágio ontológico, o "ser-aí" é entendido como existência dada num tempo determinado, o "aí", de modo a dar o fundamento do ser. Por último, ao nível ôntico-ontológico, o "ser-aí" seria determinado pelo ser pela sua ação no mundo, a qual é o princípio de realização das ontologias tradicionais. Mesmo levando em consideração estas três etapas de conhecimento do ser, Heidegger propõe uma nova ontologia, cujo fundamento é a verdade do ser irredutível à sua entificação e atuação cotidiana.

5 No existencialismo, cuja reflexão é bastante tributária das concepções heideggerianas de ser, a existência precede a essência. Esta, por sua vez, encontra-se apenas como possibilidade e somente é definida pela atuação do homem no mundo.

6 Em Nauro Machado, Funil do ser, p. 5. 


\section{REFERÊNCIAS}

Barbosa Filho, Hidelberto. Nauro Machado: poeta do ser e da linguagem. São Paulo: Global, 2005. (Coleção Melhores Poemas).

Coelho, Wilson. Heidegger e Artaud: o percurso da angústia. Disponível em: $<\mathrm{http}$ //criticanarede.com/his_heidegger.html>. Acesso em: 21 jun. 2005.

Machado, Nauro. Antologia poética. São Paulo: Quíron/MEC, 1980.

Machado, Nauro. Do eterno indeferido. Rio de Janeiro: Porta de Livraria, 1971.

Machado, Nauro. Os parreirais de Deus. São Luís: Fundação Cultural do Maranhão, 1975.

Machado, Nauro. A antibiótica nomenclatura do inferno. São Luís: Sioge, 1977.

Machado, Nauro. O anafilático desespero da esperança. Rio de Janeiro: Antares, 1988.

Machado, Nauro. Funil do ser. São Luís: EDUFMA, 1995.

Machado, Nauro. A travessia do Ródano. São Luís: Func, 1997.

Machado, Nauro. O calcanhar do humano. São Luís: Sioge, 1981.

Machado, Nauro. Antologia poética. Rio de Janeiro: Imago/Universidade de Mogi das Cruzes/Biblioteca Nacional, 1998.

Machado, Nauro. Nau de Urano. São Paulo: Siciliano, 2002.

Machado, Nauro. Nauro Machado. Seleção de Hildeberto Barbosa Filho. São Paulo: Global, 2005. (Coleção Melhores Poemas).

Foucault, Michel. O que é um autor. Lisboa: Passagens, 1992.

Heidegger, Martin. Conferências e escritos filosóficos. São Paulo: Nova Cultural, 1999. (Coleção Os Pensadores).

Heidegger, Martin. Ser e tempo: parte I. Tradução de Márcia de Sá Cavalcante. Petrópolis: Vozes, 1997. (Coleção Pensamento Humano).

HeidegGer, Martin. Sobre o humanismo. Introdução, tradução e notas de Emmanuel Carneiro Leão. Rio de Janeiro: Tempo Brasileiro, 1967.

Mounier, Emmanuel. Introdução aos existencialismos. Tradução de João Bérnard da Costa. São Paulo: Duas Cidades, 1963.

NiETZsche, Friedrich. Obras incompletas. Seleção de textos de Gerard Lebrun; tradução e notas de Rubens Rodrigues Torres Filho; posfácio de Antonio Cândido. São Paulo: Nova Cultural, 1999. (Coleção Os Pensadores). 
Olson, Robert G. Introdução ao existencialismo. Tradução de Djalma Forjaz Neto. Brasília: Brasiliense, 1970.

Penha, João da. O que é existencialismo? São Paulo: Brasiliense, 2001.

Ricoeur, Paul. De l'interpretation: essai sur Freud. Paris: Seuil, 1965.

Ricoeur, Paul. Le conflit des interpretations. Paris: Seuil, 1969.

Ricoeur, Paul. Temps et récit, v. I, II, III. Paris: Seuil, 1983, 1984, 1985.

Ricoeur, Paul. Du texte à l'action. Paris: Seuil, 1986.

Ricoeur, Paul. Tempo e narrativa. Tomos I, II, III. Tradução de Roberto Leal Ferreira. Campinas: Papirus, 1997.

SARTRE, Jean-Paul. O existencialismo é um humanismo. Tradução de Vergílio Ferreira. Rio de Janeiro: Abril Cultural, 1973. (Coleção Os Pensadores).

WAHL, Jean. Esquisse pour une histoire de l'existencialisme suivie de Kafka et Kierkegaard. Paris: L’Arche, 1949. 